\title{
PENINGKATAN KESADARAN PENTINGNYA PENDIDIKAN KELUARGA MELALUI PELATIHAN PARENTING DI DESA KAUMAN KECAMATAN SEDAYU KABUPATEN GRESIK
}

\author{
Suhartono ${ }^{1}$, Atnuri ${ }^{1}$, Bernadetta Budi Lestari ${ }^{1}$ \\ ${ }^{1}$ Universitas PGRI Adi Buana, Surabaya, Indonesia \\ suhartono@unipasby.ac.id
}

\begin{abstract}
Abstrak: Keluarga merupakan lingkungan awal bagi anak yang memiliki peran strategis dalam mendukung penyelenggaraan pendidikan. Oleh karenanya, pemahaman tentang pentingnya parenting sangat dibutuhkan untuk meningkatkan kualitas pendidikan keluarga. Tujuan pelaksanaan kegiatan pengabdian kepada masyarakat (PKM) ini adalah untuk memberikan pemahaman tentang pentingnya parenting dalam keluarga yang merupakan tanggungjawab bersama dari orang tua, masyarakat, sekolah, dan pemerintah. Kegiatan PKM ini dilaksanakan di Desa Kauman, Kecamatan Sedayu, Kabupaten Gresik. Metode yang digunakan dalam kegiatan ini adalah pelatihan dengan ceramah, diskusi, dan games. Materi yang diberikan dalam pelatihan ini meliputi pengertian, aturan, penerapan parenting yang tepat, pihak-pihak yang harus berperan dalam terwujudnya parenting, dan bahaya yang ditimbulkan jika parenting dilakukan secara tidak tepat. Hasil kegiatan ini menunjukkan pemahaman peserta terhadap parenting sebelum dilaksanakan kegiatan adalah sebesar $16 \%$. Setelah mengikuti pelatihan dalam PKM ini, pemahaman peserta terhadap parenting adalah sebesar 83\%. Hasil ini menunjukkan kegiatan PKM ini dapat meningkatkan pemahaman masyarakat tentang parenting yang bekontribusi pada kesadaran masyarakat terhadap pentingnya pendidikan keluarga.
\end{abstract}

Kata Kunci: parenting, orang tua, masyarakat, pemerintah

\begin{abstract}
Family is the initial environment for children who have a strategic role in supporting the delivery of education. Therefore, an understanding of the importance of parenting is needed to improve the quality of family education. This community service program aims to provide the parents an understanding of the importance of parenting in the family as a shared responsibility of parents, community, schools, and government. This progam was conducted in Kauman Village, Sedayu District, Gresik Regency. The method used was training with lectures, discussions, and games. The material provided in this training included the understanding, rules, proper application of parenting, parties who must play a role in the realization of parenting, and the dangers posed if parenting is done incorrectly. The results showed that participants' understanding of parenting before the training was $16 \%$. After attending the training, participants' understanding of parenting was $83 \%$. This shows that this program increases parents' understanding of parenting that contributes to community awareness of the importance of family education.
\end{abstract}

Keywords: parenting, parents, society, government

\section{Pendahuluan}

Keluarga merupakan lingkungan awal dan memiliki peran strategis dalam mendukung penyeleggaraan pendidikan bagi anak. Generasi yang unggul akan tercipta apabila diterapkan pola asuh yang benar. Dalam situasi ini, orang tua memegang peranan utama dalam proses pembelajaran anak-anaknya, terutama dikala mereka belum dewasa (Lestari, 2008). Sehingga, parenting merupakan salah satu upaya pendidikan yang bisa dilakukan oleh keluarga, lingkungan masyarakat, dengan mengutamakan sumber-sumber belajar yang 
tersedia dalam keluarga dan lingkungan masyarakat yang berbentuk kegiatan belajar secara mandiri, pola tata kerama yang baik dan santun, lingkungan yang penuh keteladanan yang sehat dalam lingkungan masyarakat. Parenting adalah cara orangtua terhadap anak-anaknya dimana mereka melakukan serangkaian usaha aktif, karena keluarga merupakan lingkungan kehidupan yang dikenal anak untuk pertama kalinya dan untuk seterusnya anak belajar didalam kehidupan keluarga (Gunarsa dalam Mauanah dan Suprijono, 2016). Tujuan dari parenting ini adalah sebagai wadah komunikasi antara orangtua dan praktisi pendidik sehingga dapat bertukar informasi dalam hal mendidik anak untuk dijadikan generasi yang berkualitas. Menurut Riana (2003), Keluarga memiliki peranan penting untuk memberikan dasar pendidikan, sikap serta keterampilan dasar, seperti: pendidikan agama, budi pekerti, sopan santun, estetika, kasih sayang, rasa aman, dasar-dasar untuk mematuhi peraturan-peraturan, dan menanamkan kebiasaan-kebiasaan.

Keluarga adalah unit terkecil dari masyarakat yang terdiri atas kepala keluarga dan beberapa orang yang terkumpul dan tinggal di suatu tempat di bawah suatu atap dalam keadaan saling ketergantungan. Keluarga merupakan salah satu pusat pendidikan. Keluarga memiliki kekhasannya sendiri yang berbeda dengan lembaga pendidikan yang lain. Di dalam keluarga, pendidikan bukan berjalan atas dasar ketentuan yang memang diformalkan, akan tetapi tumbuh dari kesadaran moral sejati antar orangtua dan anak. Keluarga juga memiliki kewajiban mengajarkan nilai-nilai dan tingkah laku yang sesuai dengan norma-norma yang ada di masyarakat. Tidak kalah penting, kemitraan sekolah dengan keluarga memiliki dampak yang besar, diantaranya adalah: (1) Keluarga merupakan pendidik yang pertama dan utama, tetapi dalam praktiknya masih banyak keluarga yang menyerahkan sepenuhnya tanggung jawab pendidikan anak pada sekolah; (2) Peran sekolah adalah membantu keluarga agar pelaksanaan pendidikan lebih sistimatis, efektif, dan hasilnya tersertifikasi; (3) Tidak semua kebutuhan pendidikan anak dapat dipenuhi oleh satuan pendidikan maupun keluarga; (4) Kerjasama keluarga dengan satuan pendidikan mutlak diperlukan; (5) Satuan pendidikan wajib mendorong kemitraan dan keikutsertaan keluarga dalam memajukan pendidikan anak mereka (Raraswati, 2016).

Menurut Jhonson (1988) peranan keluarga menggambarkan seperangkat perilaku antar pribadi, sifat, kegiatan yang berhubungan dengan pribadi dalam posisi dan situasi tertentu. Peranan pribadi dalam keluarga didasari oleh harapan dan pola perilaku dari keluarga, kelompok dan masyarakat. Orang tua adalah orang yang pertama dikenal anak. Sebagai orang yang pertama dikenal anak, orang tua mempunyai peranan penting dalam meningkatkan kualitas pendidikan dalam suatu keluarga. Berbagai peranan yang terdapat dalam keluarga adalah sebagai berikut: a) Ayah sebagai suami dari istri dan ayah dari anakanaknya, berperan sebagai pencari nafkah, pendidik, pelindung dan pemberi rasa aman, sebagai kepala keluarga, sebagai anggota dari kelompok sosialnya serta sebagai anggota dari kelompok sosialnya serta sebagai anggota masyarakat dari lingkungannya. b) Ibu sebagai istri dan ibu dari anak-anaknya, ibu mempunyai peran untuk mengurus rumah tangga, sebagai pengasuh dan pendidik anak-anaknya, pelindung dan sebagaisalah satu kelompok dari peranan sosialnya serta sebagai anggota masyarakat dari lingkungannya, di samping itu 
juga ibu dapat berperan sebagai pencari nafkah tambahan dalam keluarganya. c) Anakanak melaksanakan peranan psikosial sesuai dengan tingkat perkembangannya baik fisik, mental, sosial, dan spiritual. Karena pentingnya peranan orang tua dalam sebuah keluarga terhadap tumbuh kembang dan peningkatan pendidikan anak, maka diharapkan setiap keluarga menjalankan perannya dengan sebaik-baiknya. Menurut Prasanti \& Fitriani (2018) sebagai orangtua, tanpa disadari, sikap orang tua yang negatif pada anaknya pun justru akan menjatuhkan anak tersebut. Misalnya, ketika orang tua memukul dan memberikan tekanan yang menjadikan anak bersikap negatif, rendah diri, minder, penakut, dan tidak berani mengambil resiko, yang di mana karakter-karakter tersebut akan dibawanya sampai ia dewasa.

Keluarga, sekolah dan masyarakat merupakan tri pusat pendidikan namun keluarga yang memberikan pengaruh pertama kali terhadap anak. Tri pusat pendidikan adalah tiga unsur yang sangat berperan penting dalam penting da menjadi pusat pendidikan. Keluarga merupakan pusat pendidikan yang paling penting karena keluarga adalah lembaga yang paling berpengaruh dibandingkan lembaga yang lain (Santhut \& Ahmad, 1998). Keluarga mempunyai banyak waktu bersama dengan anak dibanding dengan pusat pendidikan yang lainnya. Pendidikan dalam keluarga yang baik dan benar, akan sangat berpengaruh pada perkembangan pribadi dan sosial anak. Kebutuhan yang diberikan melalui pola asuh, akan memberikan kesempatan pada anak untuk menunjukkan bahwa dirinya adalah sebagian dari orang-orang yang berada di sekitarnya. Anak dalam sebuah keluarga mempunyai hak dan kewajiban. Hak-hak yang dimiliki oleh anak, yang harus dipenuhi oleh orang tuanya. Sedangkan orang tua wajib untuk mengajarkan dan memberi contoh tentang kewajiban anak yang harus dipenuhi. Terpenuhinya hak anak akan membuat anak merasa nyaman berada di dalam rumah.

Pemahaman masyarakat tentang parenting masih kurang. Hal ini terlihat dari tingkat kenakalan anak/remaja yang cenderung meninggi dari tahun ke tahun. Kenakalan remaja (juvenile delinquency) adalah suatu perbuatan yang melanggar norma, aturan, atau hukum dalam masyarakat yang dilakukan pada usia remaja atau transisi masa anakanak ke dewasa. Kenakalan anak/remaja merupakan gejala patologis sosial pada remaja yang disebabkan oleh suatu bentuk pengabaian sosial yang pada akhirnya menyebabkan perilaku menyimpang (Unayah \& Sabarisman, 2015). Kenakalan anak atau remaja yang terjadi dalam masyarakat antara lain tawuran, pencurian, penyalahan narkoba, dll. Selain itu kenakalan anak/remaja juga disebabkan oleh ketidakpuasan atas penegakan hukum, pengaruh media massa, dan hingga faktor politis. Selain itu Kenakalan remaja juga bisa dipicu oleh banyak hal, seperti faktor ekonomi, sosial, kultural, dan pengaruh kelompok pergaulannya. Penyebab kenakalan anak/remaja dipengaruhi oleh beberapa faktor yaitu keluarga, lingkungan, sekolah. Peranan keluarga dalam menanggulangan kenakalan remaja sangat dibutuhkan. Karena keluarga adalah pendidikan pertama bagi anak. kenakalan anak atau remaja merupakan suatu masalah yang dihadapi masyarakat yang kini semakin marak, Oleh karena itu, masalah kenakalan remaja seyogyanya mendapatkan perhatian yang serius 
dan terfokus untuk mengarahkan remaja ke arah yang lebih positif, yang titik beratnya untuk terciptanya suatu sistem dalam menanggulangi kenakalan di kalangan remaja.

Kurangnya pemahaman tentang parenting juga terjadi di masyarakat Desa Kauman Sedayu Gresik. Kauman adalah salah satu desa di Sidayu, Kabupaten Gresik yang berada di pusat kota Sidayu yang hanya seluas 4,6 ha. Masyarakat desa Kauman mempunyai perbedaan latar belakang pendidikan yang beragam, mulai dari sekolah dasar sampai perguruan tinggi. Latar belakang pendididikan yang beragam serta mata pencaharian yang beragam mempengaruhi pemahaman masyarakat tentang parenting. Menurut Manurung \& Hettie (1995) beberapa faktor yang mempengaruhi dalam pola pengasuhan orang tua adalah latar belakang pola pengasuhan orang tua, tingkat pendidikan orang tua (orang tua yang memiliki tingkat pendidikan tinggi berbeda pola pengasuhannya dengan orang tua yang hanya memiliki tingkat pendidikan yang rendah), status ekonomi serta pekerjaan orang tua. Keadaan ini mengakibatkan fungsi atau peran menjadi "orang tua" diserahkan kepada pembantu, yang pada akhirnya pola pengasuhan yang diterapkanpun sesuai dengan pengasuhan yang diterapkan oleh pembantu.

Berdasarkan observasi yang dilakukan tim pengabdi terhadap masyarakat di Desa Kauman, Sedayu, Kabupaten Gresik yaitu terdapat beberapa permasalahan yang dihadapi oleh masyakat yaitu kurangnya pemahaman masyarakat tentang parenting, asumsi yang berkembang dalam masyarakat bahwa pembentukan karakter dan pemberian pendidikan merupakan tanggung jawab sekolah (Hal ini terjadi karena sebagian besar kegiatan anak dilakukan di sekolah), kurangnya pemahaman peranan keluarga dalam peningkatan pendidikan anak, latar belakang pendidikan orang tua yang beragam yang mempengaruhi pembentukan karakter anak, kurang maksimalnya peran orang tua dalam peningkatan kualitas pendidikan anak.

Pemahaman tentang parenting untuk meningkatkan pendidikan anak dalam sebuah keluarga sangatlah penting, sehingga diperlukan suatu kegiatan yang dapat meningkatkan pemahaman tentang parenting. Berdasarkan permasalahan diatas maka tujuan kegiatan pengabdian kepada masyarakat ini adalah memberikan pengetahuan materi yang berkaitan dengan peningkatan kualitas pendidikan keluarga melalui pelatihan parenting di Desa Kauman, Sedayu, Gresik.

\section{Metode}

Metode yang digunakan dalam kegiatan pelatihan parenting untuk meningkatkan kualitas pendidikan di desa Kauman, Sedayu Kabupaten Gresik adalah metode ceramah, diskusi, dan games. Tujuan dari metode ceramah adalah memberikan pengetahuan dan pemahaman mengenai materi yang berkaitan dengan peningkatan kualitas pendidikan keluarga melalui kegiatan parenting. Metode ceramah juga bertujuan untuk memberikan penjelasan tentang pengertian, aturan, dampak yang akan terjadi apabila terdapat kesalahan dalam parenting. Sedangkan kegiatan diskusi bertujuan bertukar pendapat antara tim pengabdi dan peserta pelatihan. Dengan adanya diskusi ini, memudahkan tim pengabdi 
untuk mengetahui pemahaman peserta pelatihan games yang diberikan bertujuan untuk memberikan motivasi sekaligus memberikan hiburan agar peserta pelatihan tidak mengalami kejenuhan.

Subyek pengabdian ini adalah masyarakat RT 02, RW 01, di desa Kauman, Sedayu Kabupaten Gresik, yang berjumlah 17 orang. Sumber data yang digunakan adalah masyarakat RT 02, RW 01, di desa Kauman, Sedayu Kabupaten Gresik, yang berjumlah 17 orang. Instrumen yang digunakan adalah lembar pre-test, post-test, dan pedoman wawancara. Setelah data terkumpul, kemudian akan dilakukan pengolahan data, disajikan dan dianalisis. Data akan dianalisis dengan menggunakan indikator kategori pemahaman materi melalui pre-test dan post-test. Dalam pelaksanaan kegiatan ini terbagi menjadi 3 (tiga) tahapan yaitu; (1) persiapan, (2) pelaksanaan, (3) evaluasi. Adapun penjelasannya adalah sebagai berikut:

1. Persiapan

Pada tahapan ini tim mengidentifikasi hal-hal penting sebagai bahan persiapan kegiatan yang akan dilaksanakan. Upaya yang dilakukan pada tahap ini antara lain adalah: (a) melaksanakan observasi ke mitra; (b) menentukan metode kegiatan, dan (c) dari hasil observasi, diperoleh gambaran materi yang akan disampaikan.

2. Pelaksanaan

Kegiatan parenting di Desa Kauman Sedayu Gresik didahului dengan pre-test. Pre-test berupa soal esai dan pilihan ganda. Pre-test ini berisi tentang pertanyaan terkait dengan pemahaman masyarakat tentang parenting, pola asuh anak, pendidikan anak, peran orang tua dalam keluarga. Pre-test ini bertujuan untuk menggali pengetahuan awal parenting. Selanjutnya kegiatan dilakukan dengan memberikan pelatihan tentang materi tentang peningkatan kualitas pendidikan keluarga melalui kegiatan parenting. Kegiatan pelaksanaan pelatihan tesebut mengacu pada desain pre-test post-test design (Sugiyono, 2015). Kategori pemahaman peserta pelatihan tentang parenting tersaji dalam Tabel 1.

Tabel 1. Kategori Pemahaman peserta pelatihan tentang parenting

\begin{tabular}{ll}
\hline Skor Pemahaman tentang parenting & Kategori \\
\hline $80<x \leq 100$ & Baik \\
$65<x \leq 80$ & Sedang \\
$x \leq 65$ & Kurang \\
\hline
\end{tabular}

Berdasarkan kategori pemahaman pada tabel 1 di atas, maka peserta pelatihan dikatakan memiliki pemahaman tentang parenting apabila dalam kategori "baik".

3. Evaluasi

Pada tahapan akhir kegiatan peserta diberikan post-test, dengan tujuan untuk mengukur tingkat pemahaman peserta pelatihan terhadap materi kegiatan parenting. Hal ini bertujuan untuk memberikan feedback kepada peserta pelatihan.

Secara umum alur pelaksanaan kegiatan pengabdian masyarakat ini dituangkan dalam Gambar 1. 


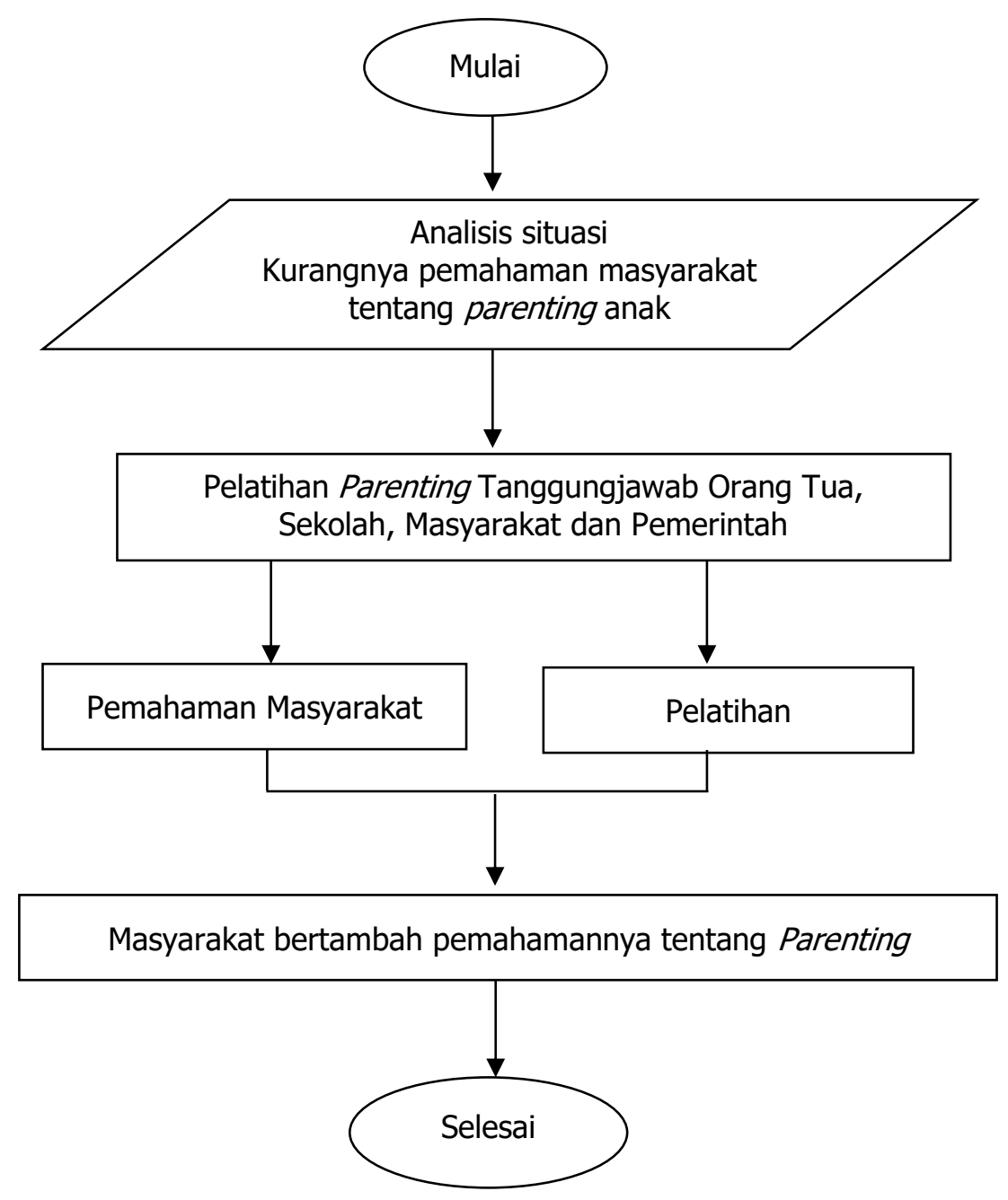

Gambar 1. Alur Pelaksanaan Pelatihan

\section{Hasil dan Pembahasan}

Berdasarkan hasil Pre-test dengan 10 soal yang kami berikan pada peserta sebelum pelatihan didapatkan data yang tersaji dalam Tabel 2 .

Tabel 2. Data hasil Pre Test

\begin{tabular}{lll}
\hline Skor Pemahaman tentang parenting & Kategori & Jumlah Peserta Pelatihan \\
\hline $80<x \leq 100$ & Baik & 6 \\
$65<x \leq 80$ & Sedang & 11 \\
$x \leq 65$ & Kurang & 20 \\
\hline
\end{tabular}

Berdasarkan tabel hasil pre test tersebut diketahui bahwa, hanya 6 peserta dari 37 peserta berada dalam kategori pemahaman yang baik tentang hakikat dari parenting, apa fungsi dan tujuan dilaksanakan parenting. Atau dapat diartikan sebanyak $16 \%$ dari peserta pelatihan yang memahami hakikat dari parenting. 
Setalah diadakan pre test, diadakan pelatihan tentang peningkatan kualitas pendidikan keluarga melalui kegiatan parenting. Hal ini dilakukan agar terjalin komunikasi dua arah antara narasumber dengan peserta pelatihan, sehingga apabila dalam proses penyampaian ada peserta yang kurang memahami materi, dapat ditanyakan kepada narasumber. Narasumber juga bisa melakukan pemetaaan pemahaman peserta kegiatan parenting. Hasil yang diperoleh dari kegiatan parenting bagi orang tua dan masyarakat ini memberikan pemahaman baru bagi warga desa Kauman Kecamatan Sedayu Kabupaten Gresik. Hal ini dibuktikan dengan nilai post-test yang kami berikan di akhir kegiatan menunjukkan hasil yang memuaskan. Dari 37 peserta yang mengikuti kegiatan ini dan kami beri post-test, sejumlah 31 peserta berada dalam karegori pemahaman yang baik. Hal ini berarti $83 \%$ peserta memahami dan mengerti hakikat parenting berdasarkan materi yang sudah disampaikan narasumber. Hasil post-test peserta pelatihan tersaji dalam Tabel 3.

Tabel 3. Hasil post test peserta pelatihan

\begin{tabular}{lll}
\hline Skor Pemahaman tentang parenting & Kategori & Jumlah Peserta Pelatihan \\
\hline $80<x \leq 100$ & Baik & 31 \\
$65<x \leq 80$ & Sedang & 4 \\
$x \leq 65$ & Kurang & 2 \\
\hline
\end{tabular}

Berikut ini adalah grafik peningkatan pemahaman pada saat pre test dan post test.

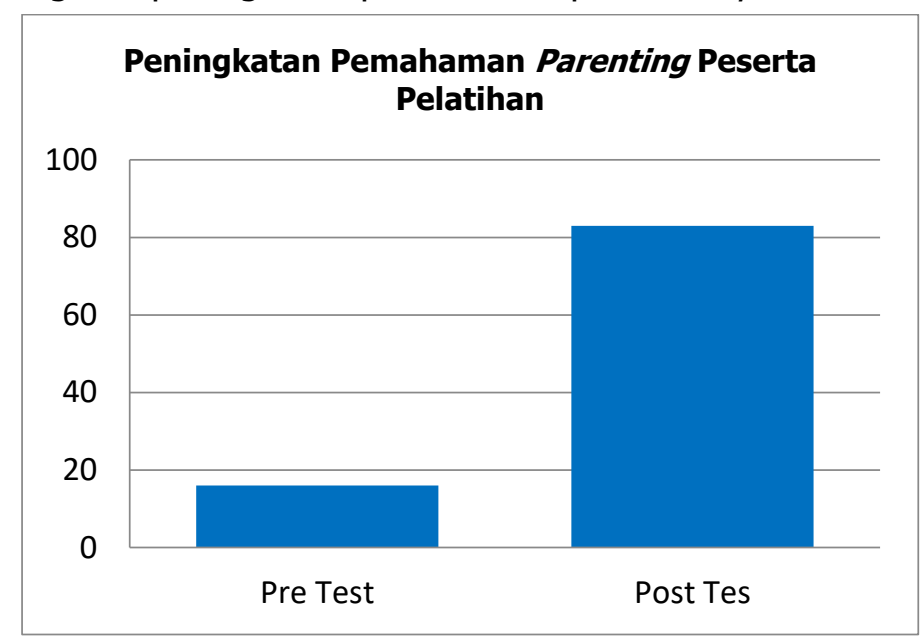

Grafik 1. Peningkatan pemahaman parenting berdasarkan hasil pre-test dan post-test

Berdasarkan Grafik 1, maka terjadi peningkatan yang cukup signifikan antara hasil pre test dengan post-test. Berdasarkan grafik tersebut, terjadi peningkatan sebesar $67 \%$. Peningkatan hasil pre test dengan post-test menunjukkan adanya peningkatan pemahaman tentang peningkatan kualitas pendidikan melalui parenting. Adanya peningkatan pemahaman menunjukkan adanya keberhasilan kegiatan pelatihan ini.

Berdasarkan hasil wawancara panitia sebelum diadakan pelatihan dengan Ibu NR yang menyatakan bahwa ibu NR lebih memahami pentingparenting dalam meningkatkan pendidikan anak. Ibu NR sebelumnya menganggap bahwa parenting hanya diperuntukkan bagi orang tua yang mempunyai anak dan anak balita. Sedangkan bapak KD menganggap 
parenting hanya diperlakukan untuk anak PAUD. Sehingga dapat disimpulkan bahwa pemahaman masyarakat Desa Kauman Kecamatan Sedayu Gresik terhadap parenting masih kurang.

Hasil wawancara pengabdi dengan beberapa peserta pelatihan setelah diadakan pelatihan menunjukkan jawaban yang cukup memuaskan. Berdasarkan hasil wawancara didapatkan hasil bahwa Ibu SA menyatakan "sangat senang mas dengan adanya kegiatan pelatihan ini". Menurut Ibu SA, sebelum ada kegiatan parenting ini, ibu SA beranggapan bahwa pendidikan anak merupakan tanggungjawab pihak sekolah. Tetapi, setelah adanya kegiatan pelatihan, ibu SA mengetahui bahwa pendidikan anak tidak hanya di sekolah, tetapi keluarga dan masyarakat juga ikut berperan serta. Sama halnya dengan ibu SA, ibu WA juga memberikan komentar terkait keberhasilan kegiatan ini. Subyek ibu WA menyatakan bahwa dirinya lebih memahami tentang peranan orang tua dalam mendidik anak setelah mengikuti pelatihan ini. Sedangkan bapak DK menyatakan peranan parenting sangat penting dalam membentuk karakter dan pendidikan anak. Peranan keluarga dan masyarakat dalam pola asuh anak sangat penting dalam membentuk karakter dan pendidikan anak. Foto pelaksanaan kegiatan tersaji dalam Gambar 1 dan Gambar 2.

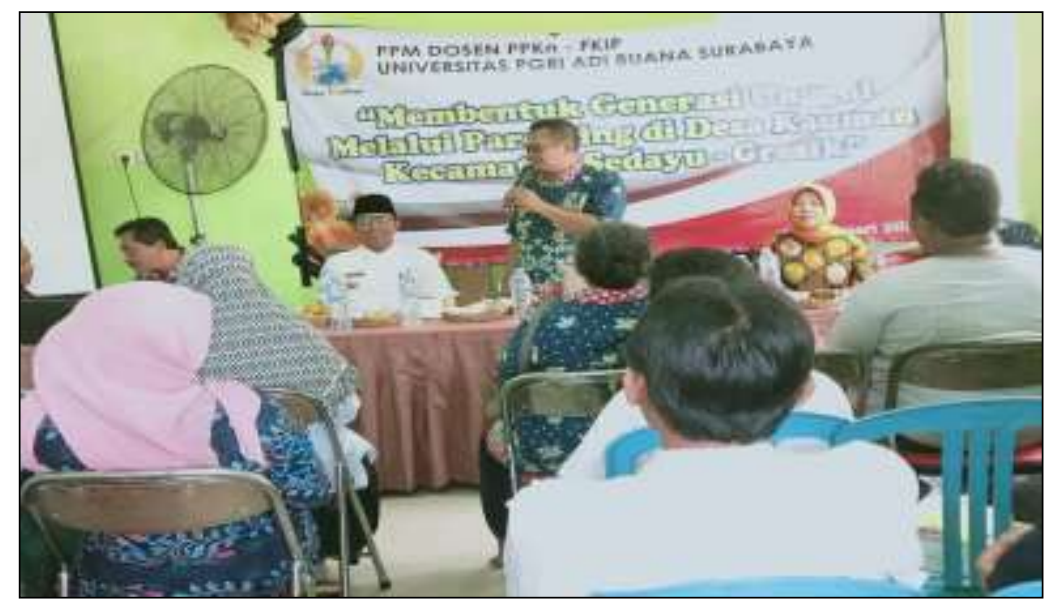

Gambar 1. Pelaksanaan Kegiatan Pelatihan

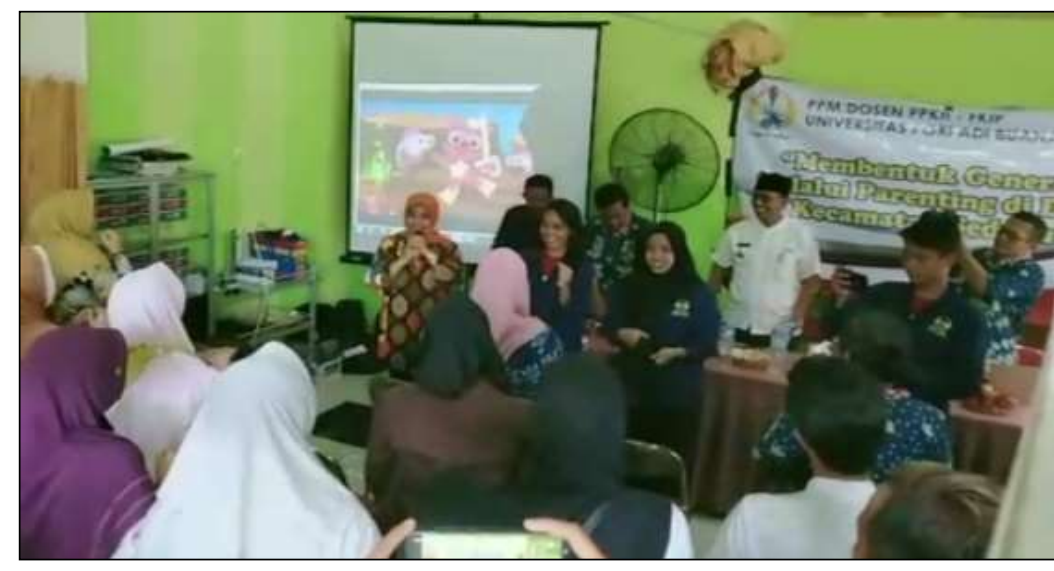

Gambar 2. Pelaksanaan Kegiatan Pelatihan 
Berdasarkan hasil kegiatan pelatihan ini dapat disimpulkan bahwa orang tua, masyarakat dan pemerintah desa mempunyai peranan masing-masing dalam kegiatan parenting di lingkungan mereka. Tidak hanya sebatas memberikan pendidikan bagi anak, namun harus terdapat sinergitas antara pendidikan bagi orang tua dan masyarakat agar pendidikan yang diberikan kepada anak di sekolah selaras dengan pendidikan di rumah dan dilingkungan masyarakat. Upaya ini bertujuan agar kegiatan dirumah sesuai dan tidak bertentangan dengan kegiatan di sekolah. Pelaksanaan program parenting menggunakan model ceramah, tanya jawab dan games, orang tua dan masyarakat diberikan pendidikan agar bertambah pengetahuan mereka terutama tentang pertumbuhan dan perkembangan anak-anak. Secara garis besar hasil kegiatan pelatihan ini dapat disimpulkan bahwa terdapat peningkatan pemahaman masyarakat Desa Kauman Kabupaten Gresik Kecamatan Sedayu Gresik tentang hakikat parenting bagi anak-anak dan lingkungannya.

\section{Kesimpulan}

Hasil kegiatan pelatihan parenting menunjukkan adanya peningkatan pemahaman masyarakat terhadap parenting. $\mathrm{Hal}$ ini terbukti dari perbedaan hasil pre-test dan post-test. Pada saat pre-test didapatkan hasil bahwa 6 peserta dari 37 peserta berada dalam kategori pemahaman yang baik tentang hakikat parenting, fungsi, dan tujuan parenting. Hal ini berarti sebanyak $16 \%$ dari peserta pelatihan yang memahami hakikat dari parenting. Sedangkan pada saat post-test didapatkan hasil bahwa 31 dari 37 peserta berada dalam karegori pemahaman yang baik. Hal ini berarti $83 \%$ peserta memahami dan mengerti hakikat parenting berdasarkan materi yang sudah disampaikan narasumber. Berdasarkan hasil wawancara setelah melakukan kegiatan pelatihan dengan 3 peserta pelatihan didapatkan hasil bahwa mereka memahami dan mengerti hakikat parenting berdasarkan materi yang sudah disampaikan narasumber.

\section{Ucapan Terima Kasih}

Keberhasilan kegiatan pelatihan tentang "Parenting Tanggungjawab Orang Tua, Sekolah, Masyarakat dan Pemerintah" yang dikemas dalam bentuk pengabdian tidak akan berhasil apabila tidak didukung oleh berbagai pihak. Untuk itu, kami sebagai tim pengabdi memberikan ucapan terimakasih kepada: a) Lembaga Penelitian dan Pengabdian Masyarakat (LPPM) Universitas PGRI Adi Buana Surabaya yang telah memberikan bantuan moril maupun materiil sehingga kegiatan PPM ini dapat terlaksana dengan baik, b) Tim Dosen Program Studi PKN yang telah bekerja keras dalam menyelenggaran kegiatan PKM ini, dan c) Masyarakat Desa Kauman Kabupaten Gresik Kecamatan Sedayu Gresik.

\section{Referensi}

Jhonson, C.L. (1988). Ex Familia. New Brunswick: Rutger University Press.

Lestari, P. (2008). Pola Asuh Anak Dalam Keluarga (Studi kasus pada pengamen anak-anak di kampung Jlagran, Yogyakarta). Dimensia, 2(1), 51-76

Manurung \& Hettie, M. (1995). Manajemen Keluarga. Bandung: Indonesia Publishing House. 
Mauanah, S. N. \& Suprijono, A. (2016). Parenting Education Sebagai Pendidikan Keluarga (Motif Keterlibatan Orang Tua Dalam Parenting Education). Paradigma, 4(1), 1-10

Prasanti, D \& Fitriani D.R. (2018). Pembentukan Karakter Anak Usia Dini: Keluarga, Sekolah, Dan Komunitas? (Studi Kualitatif tentang Pembentukan Karakter Anak Usia Dini Melalui Keluarga, Sekolah, dan Komunitas). Jurnal Obsesi : Jurnal Pendidikan Anak Usia Dini. Vol 2 (1). 13 19. DOI: https://doi.org/10.31004/obsesi.v2i1

Raraswati, P. (2016). Makalah Kebijakan Pembinaaan Pendidikan Keluarga. Kementerian Pendidikan dan Kebudayaan.

Riana, M. (2003). Pendidikan Karakter untuk Membangun Masyarakat Madani. IPPK Indonesia Heritage Foundation.

Santhut \& Ahmad, K. (1998). Menumbuhkan Sikap Sosial, Moral dan Spiritual Anak dalam Keluarga Muslim, Penerjemah: Ibnu Burdah, Yogyakarta : Mitra Pustaka.

Sugiyono. (2015). Metode Penelitian Kombinasi (Mix Methods). Bandung: Alfabeta.

Unayah, N. \& Sabarisman, M. (2015). Fenomena kenakalan remaja dan kriminalitas. Sosio Informa $1(2), 121-140$ 